\title{
Landslide trends under extreme climate events
}

\author{
Chyi-Tyi Lee* \\ Graduate Institute of Applied Geology, National Central University, Taoyuan City, Taiwan
}

\begin{abstract}
Article history:
Received 30 November 2015

Revised 15 April 2016

Accepted 28 May 2016

Keywords:

Landslides, Rainfall events,

Landslide trend, Extreme climate

Citation:

Lee, C. T., 2017: Landslide trends under extreme climate events. Terr. Atmos. Ocean. Sci., 28, 33-42, doi: 10.3319/TAO.2016.05.28.01(CCA)
\end{abstract}

\begin{abstract}
Does the incidence of landslides increase with rainfall? To what extent will landslides occur as a result of previous extreme-rainfall events? This becomes important to know under expected climate changes. This research studies the relationship between landslide density and rainfall depth in landslide susceptibility zones on the Zengwen River basin in southwestern Taiwan. The relationship is then applied to predict landslide occurrence during a near future rainfall event and a predicted extreme rainfall at the end of this century, as estimated from statistical and dynamic precipitation downscaling. The results indicate increased incidence of landslides with rainfall between a lower rainfall threshold and an upper range of values. Near the upper range of values, the rate of increase in the incidence of landslides slows, tending to become saturated at a certain landslide density. This finding is different from models proposed in previous studies which show a quadratic increase with large rainfalls. The different rates of increase for landslides with large amounts of rainfall will result in various hazards that may require special attention.
\end{abstract}

\section{INTRODUCTION}

Landslides are secondary or induced features after a triggering event, such as an earthquake, or heavy or prolonged rainfall. Rain-induced landslides are the most common type among different triggering events. Landslides occur when rainfall accumulation reaches a certain amount and pore water pressure in the soil/rock mass reaches a critical value causing sliding. The existence of a rainfall threshold has long been discussed (Caine 1980; Crosta 1998; Guzzetti et al. 2007, 2008; Saito et al. 2010). When the rainfall exceeds a threshold, the number and area of landslides may start to increase. Beyond the threshold, Daogi (1971) recommended using a quadratic model to describe the relationship between the area of triggered landslides and the amount of rainfall accumulation. Finlay et al. (1997) investigated the relationship between the probability of landslide occurrence and rainfall in Hong Kong. They utilized both a quadratic model and a cubic model that fit the rainfall data and number of landslides well although they also mentioned that the cubic model will exceed the physical limit of the number of features on Hong Kong Island. However, if there is indeed a quadratic increase in landslides with rainfall, this trend bodes ill for the future environment under extreme climate changes. The impact may include an increase in erosion and sedimentation rates, increased incidences of flooding, and even increases in seismicity (Steer et al. 2014), besides the increase in the number and severity of landslides.

Is there an upper limit density for landslides in mountainous areas? According to our landslide database in Taiwan, the event-triggered landslide density by heavy typhoon rainfall ranges from $0.5 \%$ to nearly $5 \%$ in each drainage basin and for each storm event. The maximum event-triggered landslide density caused by the 2008 Typhoon Morakot in the Gaoping River basin in southern Taiwan was $4.89 \%$. There should be a physical limit where the safety conditions remain unchanged after the slope is saturated and no more water is seeping into the ground. This is easily modeled using a rainfall infiltration model showing that the landslide density reaches a constant value after a certain cumulative amount of rainfall (e.g., Tan et al. 2009). Therefore, an upper rainfall boundary may exist for sliding on a slope, beyond which the landslide number/area would not increase. This study tests this hypothesis using actual data collected at the Zengwen River basin in southwestern Taiwan, and discusses the trend for increased landslides under extreme rainfall events.

\footnotetext{
* Corresponding author

E-mail:ct@ncu.edu.tw
} 


\section{DATA}

\subsection{Terrain Data}

Taiwan is a mountainous island with an area of $36188 \mathrm{~km}^{2}$ where the highest peak, Yushan, reaches an elevation of $3952 \mathrm{~m}$. Tectonically, Taiwan is on the active collision zone between the Asiatic Continent and the Luzon Arc, where the arc-continent collisions started in the Late Miocene and are still vigorously taking place (e.g., Teng 1990). The region is characterized by active crustal deformation (Bonilla 1975, 1977; Yu et al. 1997), frequent earthquakes (Hsu 1971; Tsai et al. 1977), numerous typhoons, and high erosion rates (Dadson et al. 2003). The Taiwan region has a subtropical climate with an average annual precipitation of about $3000 \mathrm{~mm}$ and an average temperature of about $20^{\circ} \mathrm{C}$. Physical and chemical weathering are significant and rapid, and slope wash and colluvium are widespread on hillsides.

The Zengwen River basin, located in southwestern Taiwan, geologically belongs to the Western Foothills Neogene sedimentary province (Ho 1975) (Fig. 1). The mountain terrain drainage basin is the target area examined in this study. This province has an area of $929.6 \mathrm{~km}^{2}$. The study area elevations range from $40 \mathrm{~m}$ in the southwest to $2610 \mathrm{~m}$ in the northeast, with generally rugged topography. Slopes with gradients greater than $55 \%$ cover $55.2 \%$ of the study area, slopes with gradients of $30-55 \%$ occupy $39.6 \%$ of the area, while only $5.2 \%$ is comprised of gentle slopes with gradients less than $30 \%$. The rocks are composed of folded and faulted Miocene and Pliocene sandstone and mudstone. Terraces on the river sides are composed of sandy gravels and they may be covered by lateritic soils on high terraces. Slopes are commonly mantled by shallow slope washes or colluvium. Nearly $90 \%$ of the study area is forested. The climate is influenced by typhoons in summer with winter being the dry season.

Geological maps (1:50000) were obtained from the Central Geological Survey, Taiwan. Each map was overlaid with a shaded Digital Elevation Model (DEM) and visually inspected in a Geographic Information System (GIS). Some abnormal boundaries, mostly associated with alluvial and terrace deposits, were corrected. A shaded geological map is shown in Fig. 2.

The $5 \times 5 \mathrm{~m}$ DEMs were acquired from the Department of Interior, Taiwan and were visually checked using a colorshaded image of the DEM. When a defect of more than a few pixels in size was found, this portion was re-digitized from a 1:5000 scale photo-based contour map. Other abnormal random points were corrected using a median filter. The DEM was finally smoothed a little and reduced to a $10 \mathrm{~m}$ grid for subsequent analyses.

\subsection{Landslide Inventories}

False-color SPOT images were used for landslide rec- ognition. Image interpretation was based on image tone, shape, association, and personal experience. The landslides were digitized in GIS and attributes assigned to establish a landslide map and table. Each landslide map was then checked against recent rectified aerial photographs via the GIS. Most misinterpretations due to man-made features or cultivated land could be recognized during this comparison. The landslide tables were further modified using ground data obtained from field checks, forming a landslide

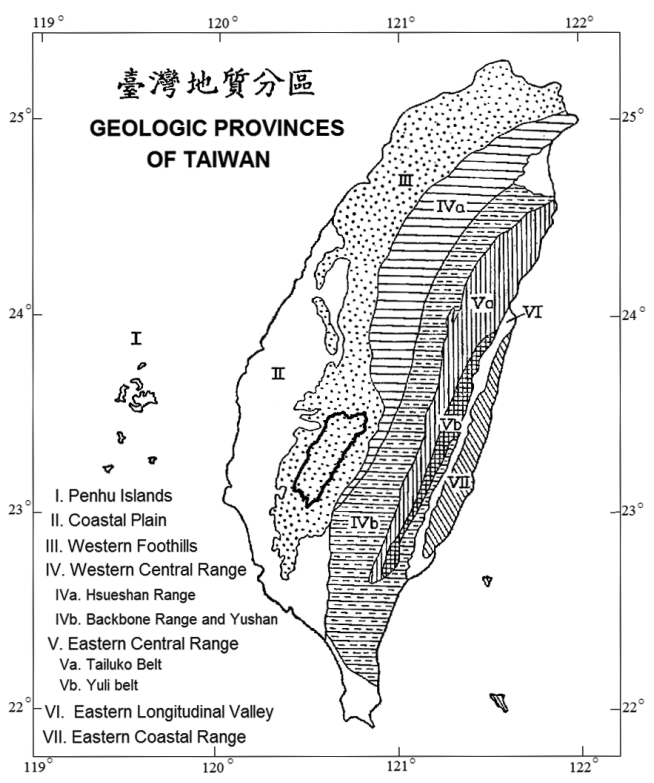

Fig. 1. Map of the study area geology and location (thick line).

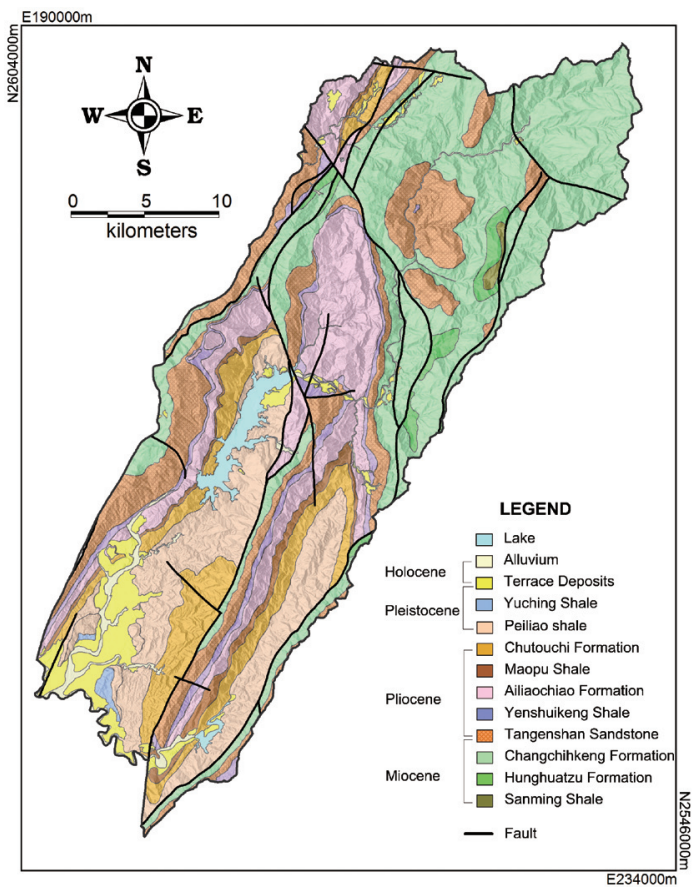

Fig. 2. Geological map of the study area. 
inventory. Landslide types, which include disruptive shallow landslides, cohesive deep-seated landslides, and others, were noted after examining the landslide's shape, scarring and deposition on SPOT images, photo-based maps, and by field checking. These data were also recorded as attributes for each landslide object in the GIS.

Landslide deposits were identified by comparing the GIS landslide layer with a set of new 1:5000 scale photobased contour maps. The slope angle or contour line concentration was used to differentiate deposits from sliding and source areas. The final GIS landslide inventory included a detailed description of the date/event, source/deposit, size, and type of each landslide object. Finally, pre-event, post-event, and event-triggered landslide inventories were made.

Event-triggered landslides were identified by comparing the pre-event and post-event landslide inventories, producing an event landslide inventory. An event-triggered landslide could be absent from the pre-event landslide inventory, or present in both inventories. Landslides found in both inventories were carefully examined for changes in tone and/or enlargement in extent, for determination of an event-triggered landslide. Four event-triggered landslide inventories (Fig. 3), were completed in this study. The events and images used are listed in Table 1. Both multi-spectral (XS) and panchromatic (PAN) images were used with a fusing technique (Liu 2000) to produce a higher resolution false-color composite image to facilitate landslide recognition. The pixel resolution after fusing is $6.25 \mathrm{~m}$ for SPOT1 - SPOT4, and is $2.5 \mathrm{~m}$ for SPOT5.

\subsection{Rainfall Data}

Hourly rainfall data from 166 rain gauge stations in and around the study area were used to process rainfall parameters at each station. These point data were spatially interpolated to each raster cell in the study area. Kriging with varying local means (Goovaerts 1997) was used to include elevation data as an auxiliary variable in the rainfall value interpolation. The data for maximum hourly rainfall, rolling 24-h rainfall, and total event rainfall for Typhoons Herb, Haitang, Kalmaegi, and Morakot were processed. Distributions of the total event rainfalls for the four Typhoon events are shown in Fig. 4.

Rainfall predictions at near future and at the end of this century, estimated from statistical and dynamic precipitation downscaling are also included in this study to facilitate probing for landslide trends under climate extremes. Two sets of simulated rainfall adopted from the Taiwan Climate Change Projection and Information Platform (TCCIP) are used to estimate landslide occurrence in the study area. The first set data represents a near future rainfall event from 8 to 11 July 2017 (Fig. 5a). The second set data represents end of the century rainfall from 14 to 17 July 2090 (Fig. 5b). For the Details of this, method and procedure for the simulated rainfalls refer to $\mathrm{Su}$ et al. (2014).

\section{ANALYSIS AND RESULTS}

The purpose of this analysis is to find the relationship between landslide density and rainfall. However, the relationship is not so simple, because slope gradient, soil strength, hydrologic parameters, and others factors also influence the landslide density. It has long been known that the combined effect of the above-mentioned parameters is the landslide susceptibility (Carrara 1983; Varnes 1984; Aleotti and Chowdhury 1999; Guzzetti et al. 1999), which differentiates a region into several successive classes representing relative slope stability. Therefore, if we fix the susceptibility or take the susceptibility as the independent variable in the density-rainfall relationship, determining the relationship between landslide density and rainfall could become possible.

\subsection{Terrain Susceptibility Model}

In building a susceptibility model, the effective susceptibility factors (Lee 2013) for landslides were selected first. These include the slope gradient, slope aspect, slope roughness, tangential curvature, relative slope height, lithologic units, and total event rainfall. Training data were then selected from the Herb event landslide inventory and the Haitang event landslide inventory for building a susceptibility model. The methodology used in the landslide susceptibility analysis basically follows that used by Lee et al. (2008).

This analysis is a 10-m grid-based study. In total 62678 landslide grid-cells, randomly selected non-landslide cells, and relevant factor values for each cell were selected for logistic regression. The logistic model is formulated as follows:

$$
\begin{aligned}
& -1.021 L_{1}+0.848 L_{2}+0.59 L_{3}+1.052 L_{4}+ \\
& 1.076 L_{5}+0.988 L_{6}+0.536 L_{7}+1.074 L_{8}+ \\
& \ln \left(\frac{p}{1-p}\right)=\begin{array}{l}
3.01 A_{1}+3.918 A_{2}+4.397 A_{3}+4.622 A_{4}+ \\
4.566 A_{5}+4.321 A_{6}+3.717 A_{7}+3.018 A_{8}+
\end{array} \\
& 0.796 F_{1}+0.215 F_{2}+0.192 F_{3}-0.302 F_{4}+ \\
& 0.135 F_{5}-5.286
\end{aligned}
$$

where $L_{1}-L_{8}$ are lithologic units as listed in Table 2; $A_{1}-A_{8}$ are slope aspect factors; $F_{1}-F_{4}$ are the causative factors, slope gradient, slope roughness, tangential curvature, relative slope height, respectively; $F_{5}$ is the triggering factor event total rainfall; and $p$ is the occurrence probability. The value of $p$ could be taken as the landslide susceptibility from which a susceptibility map is drawn (Fig. 6). This model is evaluated with fairly good results with an Area Under 
Curve (AUC) of the success rate curve (Chung and Fabbri 1999 ) of 0.776 . This model is then validated using the Kalmaegi event landslides and the Morakot event landslides. The prediction rate (Chung and Fabbri 2003) for Kalmaegi event landslides and Morakot event landslides are 0.751 and 0.708 , respectively. The success rate and the prediction rates are fairly good and indicate it is an acceptable model.

The aforementioned susceptibility model is an eventbased model that is trained with event-triggered landslides and a triggering factor (Lee et al. 2008), and thus the model is event dependent (Fig. 6a). However, if we remove the triggering factor from the model, it then becomes event independent (Fig. 6b), supposing that the triggering factor is independent of other causative factors. There is a basic susceptibility in a region regardless of what event landslides are used to build a model (Lee 2015). Figure $6 \mathrm{~b}$ could be a basic susceptibility model for the present study region.

\subsection{Landslide and Rainfall Relationship}

We used the four landslide event inventories and rainfall value at each corresponding grid of a triggered landslide to test the relationship between the probability of failure (landslide density) and event total rainfall at each basic susceptibility bin. The result shows that the probability of failure increases with an increase in the rainfall and also an increase in the susceptibility (Fig. 7a). A fitting surface of probability for landslide failure using a rainfall parameter and the basic susceptibility as two independent variables was done. The result is shown in Fig. 7b and Eq. (2) as follows:
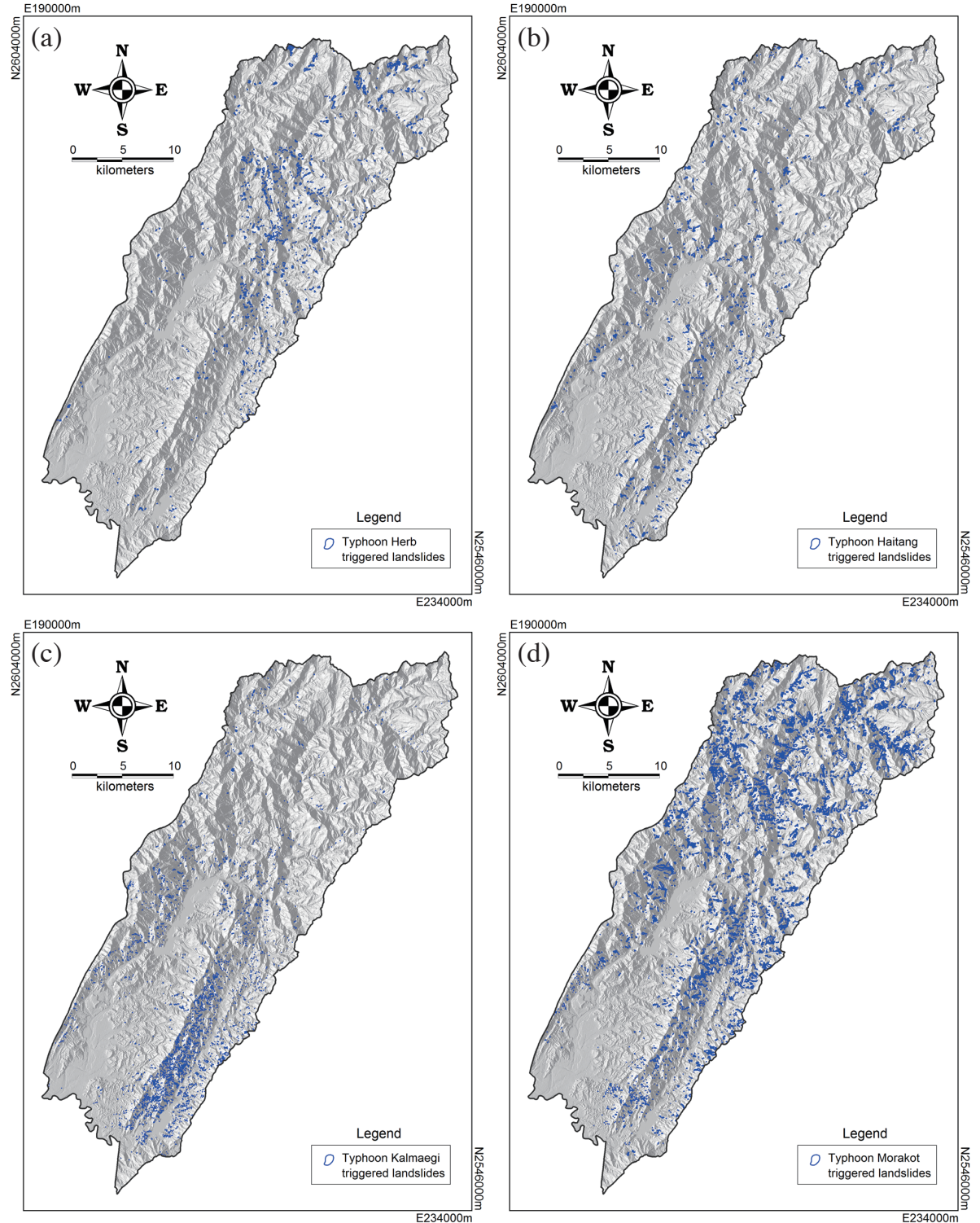

Fig. 3. Event-triggered landslide inventories in the study area. (a) Typhoon Herb triggered landslides; (b) Typhoon Haitang triggered landslides; (c) Typhoon Kalmaegi triggered landslides; (d) Typhoon Morakot triggered landslides. (Color online only) 
Table 1. Typhoon events and spot images used in the study.

\begin{tabular}{c|c|c|c}
\hline Typhoon & Duration & Dates of spot images used & Image \\
\hline Typhoon Herb & $1996 / 07 / 29-1996 / 08 / 01$ & $\begin{array}{c}\text { Pre-event: } 96 / 01 / 28,96 / 04 / 17 \\
\text { Post-event: } 96 / 08 / 21,96 / 11 / 08,96 / 12 / 05\end{array}$ & SPOT1 - SPOT4 \\
\hline Typhoon Haitang & $2005 / 07 / 16-2005 / 07 / 20$ & $\begin{array}{c}\text { Pre-event: 05/01/23, 05/03/06, 05/03/21 } \\
\text { Post-event: 05/11/26, 05/11/27, 05/12/24 }\end{array}$ & SPOT5 \\
\hline Typhoon Calmaegi & $2008 / 07 / 16-2008 / 07 / 18$ & $\begin{array}{c}\text { Pre-event: 07/12/21 } \\
\text { Post-event: 08/11/12,08/11/28 }\end{array}$ & SPOT5 \\
\hline Typhoon Morakot & $2009 / 08 / 05-2009 / 08 / 10$ & $\begin{array}{c}\text { Pre-event: 09/01/03 } \\
\text { Post-event: 09/09/20,09/11/01,09/11/02 }\end{array}$ & SPOT5 \\
\hline
\end{tabular}

Note: The SPOT1 - SPOT4 resolution is $6.25 \mathrm{~m}$, and that of SPOT5 is $2.5 \mathrm{~m}$.
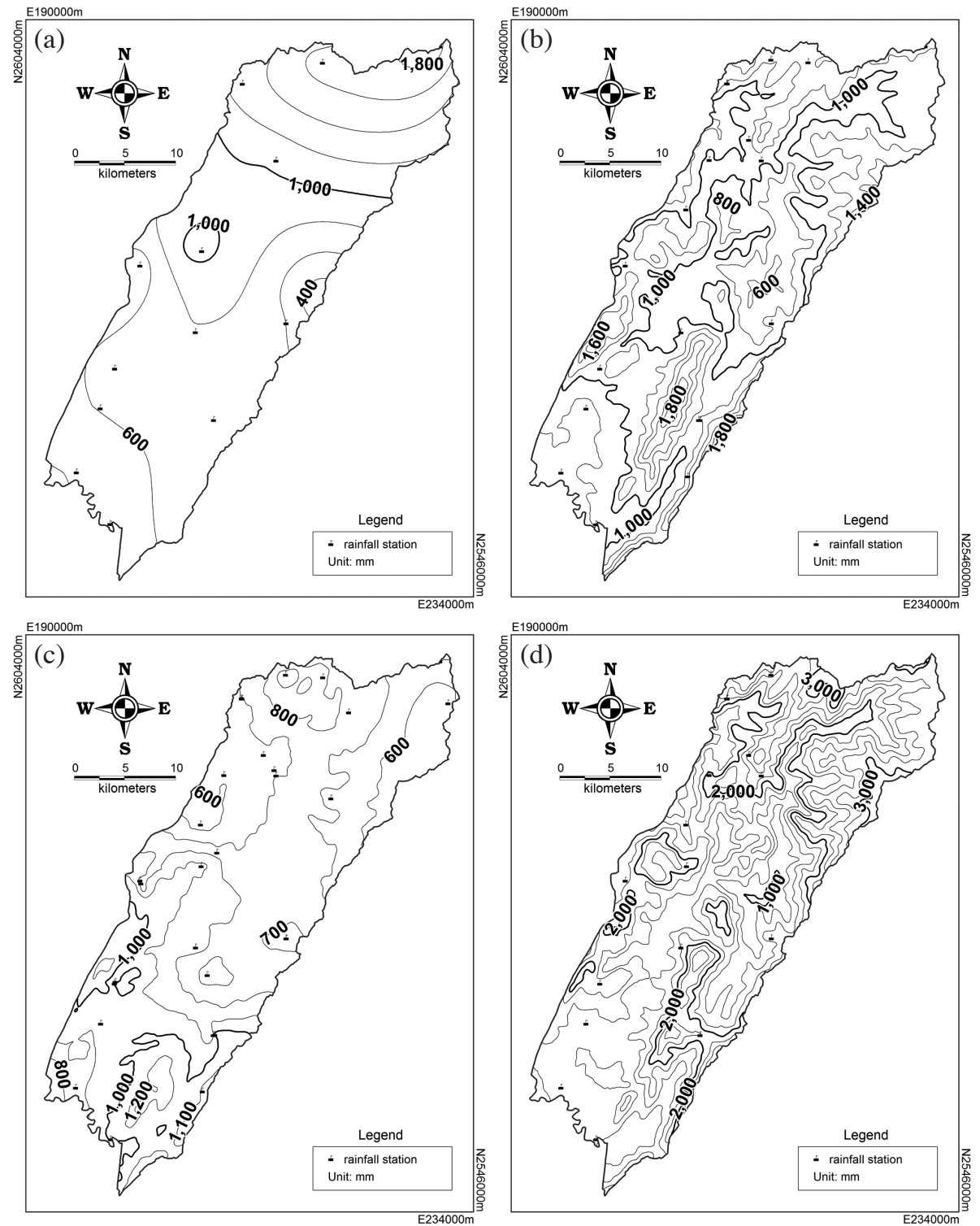

Fig. 4. Cumulative rainfalls in the study area. (a) Typhoon Herb; (b) Typhoon Haitang; (c) Typhoon Kalmaegi; (d) Typhoon Morakot. 
(a)

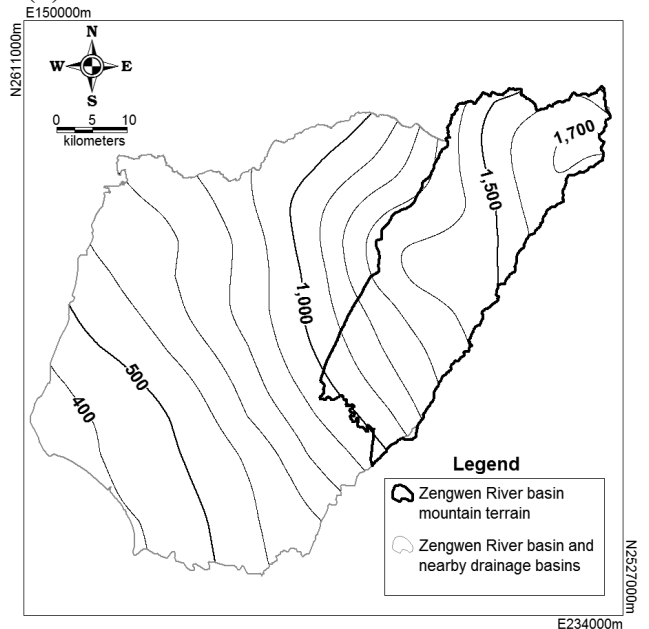

(b)

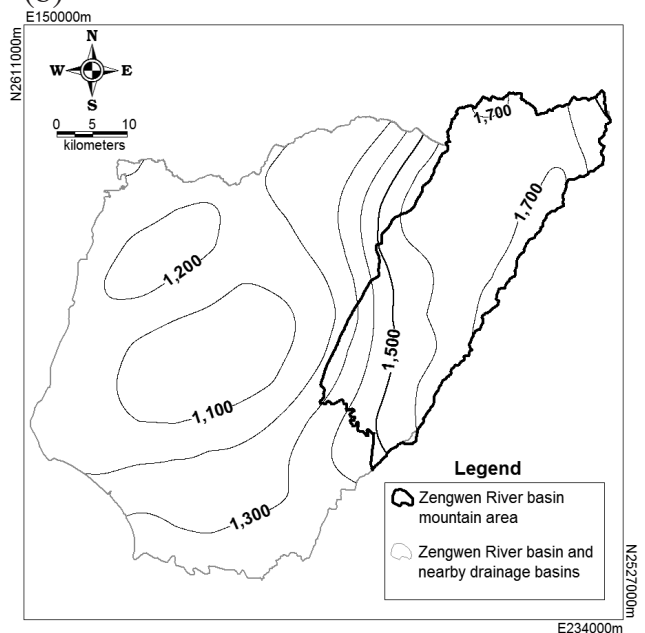

Fig. 5. Rainfall predictions estimated from statistical and dynamical downscaling of precipitation: (a) near future rainfall event from 8 to 11 July 2017; (b) rainfall at the end of the century from 14 to 17 July 2090 (adopted from the Taiwan Climate Change Projection and Information Platform, TCCIP).

Table 2. Stratigraphy and lithologic units delineated in the study area.

\begin{tabular}{c|c|c}
\hline Unit & Lithology & Stratigraphy \\
\hline 0 & Gravel, sand, silt and clay & Alluvium \\
\hline 1 & Gravel, sand, silt, clay, and lateritic soil & Terrace deposits \\
\hline 2 & Mudstone, sandy shale intercalated with sandstone & Yuching Shale, Peiliao Shale \\
\hline 3 & Alternation of sandstone and shale & Chutouchi Formation \\
\hline 4 & Shale, partly intercalated with sandstone & Maopu Shale \\
\hline 5 & Alternation of sandstone and shale & Ailiaochiao Formation \\
\hline 6 & Shale and sandy shale & Yenshuikeng Shale \\
\hline 7 & Massive sandstone, partly intercalated with shale & Tangenshan Sandstone \\
\hline 8 & Bedded sandstone, alternation of sandstone and shale, shale & Changchihkeng Formation, Hunghuatsu Formation, and Sanming Shale \\
\hline
\end{tabular}
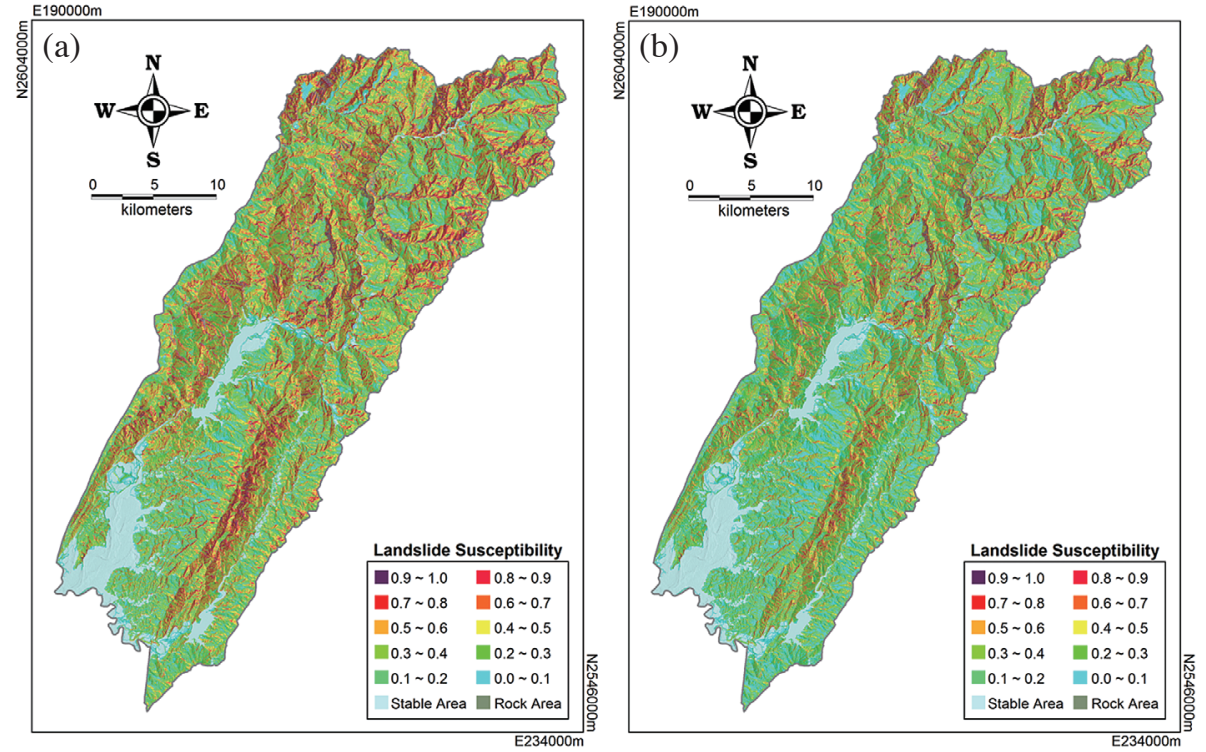

Fig. 6. Landslide susceptibility maps for the Zengwen River basin mountainous terrain in southwestern Taiwan: (a) susceptibility map with triggering factor; (b) susceptibility map without triggering factor (basic susceptibility map). Stable area is assigned to the area where slope gradient is less than $10 \%$ and area is larger than 1 ha., rock area is assigned to those very steep rock cliffs where area is larger than 0.5 ha. Both stable area and rock area are not included in building the model and further use. 

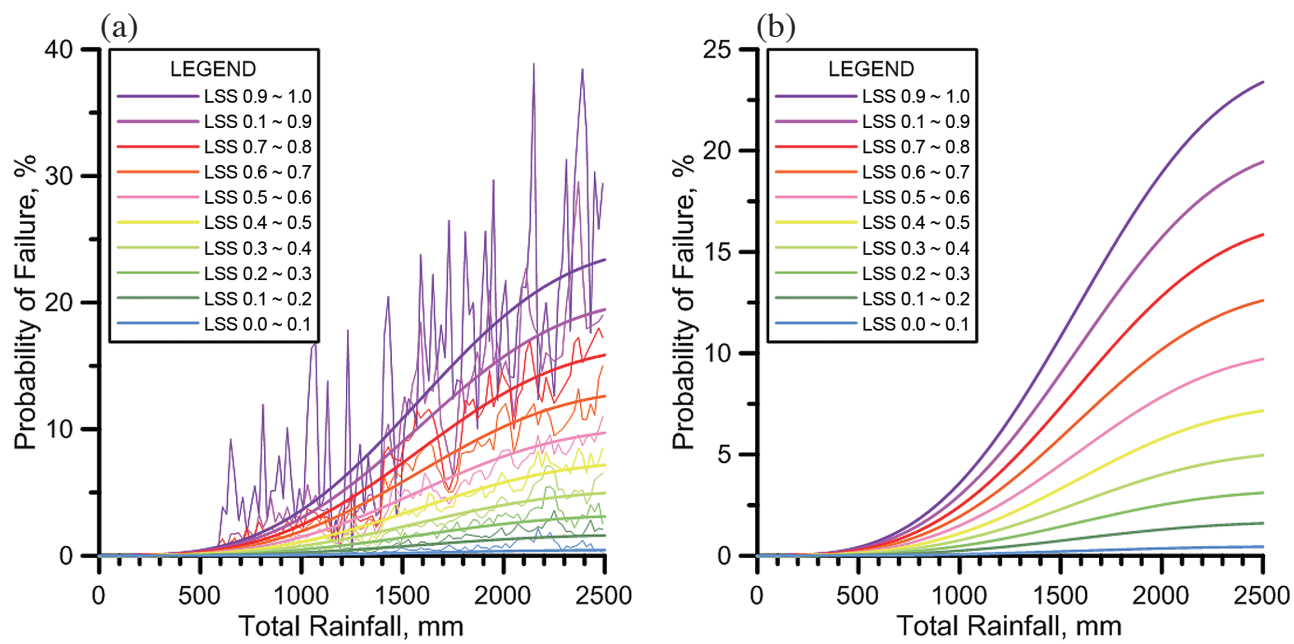

Fig. 7. Landslide and rainfall relationship for the Zengwen River basin mountainous terrain in southwest Taiwan: (a) fit for each susceptibility bin; (b) total fit (equation is shown in the text).

$y=\lambda(18.3477 \lambda+8.4982)\left[1-e^{-0.0000965\left(\frac{x}{100}\right)^{3.2125}}\right]$

where $x$ is the event total rainfall in $\mathrm{mm} ; y$ is the probability for landslide failure; and $\lambda$ is the basic susceptibility.

This function is basically a Weibull cumulative distribution function, if the basic susceptibility $\lambda$ is fixed. It shows that probability for landslide failure increases when the rainfall depth is between a lower threshold and an upper bound, and near the upper bound, the incidence of landslide failure increases slowly and tends towards saturation. This finding is different from models proposed in previous studies, which indicate that the rate of increase follows a quadratic trend with large amounts of rainfall.

\subsection{Prediction of Landslides for Rainfall Scenarios}

Applying the landslide susceptibility model and the above-mentioned relationship, and substituting in a scenario rainfall, landslides may be predicted. Two sets of simulated rainfall data adopted from TCCIP are used to estimate landslide occurrence in the study area.

The first set of data, representing a near future rainfall event from 8 to 11 July 2017 are used to produce the probability for landslide failure map shown in Fig. 8a, and predict a total landslide area of $19631806 \mathrm{~m}^{2}$ (2.11\% study area). The second set of data, representing rainfall at end of the century from 14 to 17 July 2090, result in the probability for landslide failure map shown in Fig. 8b, and predict a total landslide area of $25885700 \mathrm{~m}^{2}$ (2.78\% study area). The difference in landslide area between these 73 years is $6253894 \mathrm{~m}^{2}$ $(0.67 \%$ of the study area).

\section{DISCUSSION}

It is clear from previous studies and the present study that the incidence and severity of landslides increase with rainfall when the amount exceeds a threshold. Does an upper limit for landslide density exist? Will the rate of increase become lower or level off at a certain landslide density? The present study indicates that the rate of increase is neither constant nor quadratic with increased rainfall, but may tend to level off after the amount of rainfall exceeds a certain value.

The physical meaning of the upper-boundary to the landslide trend may be realized by using a rainfall infiltration model. There is a limit to groundwater penetrating the slope surface, because the rainfall becomes surface runoff; there is no further increase in pore water pressure in the slope and no further lowering of the slope stability factor. The quadratic model proposed by Daogi (1971) and Finlay et al. (1997) is not appropriate for this purpose and requires modification.

The present proposed model is a Weibull cumulative distribution function, if the susceptibility value is fixed. This model appears to conveniently fit the landslide and rainfall relationship in the present study area. The landslide incidence increases with the accumulated rainfall between the lower rainfall threshold and through a range of values beyond which the rate of increase slows and tends to become saturated at a certain landslide density. This model is found to be applicable for drainage basins which we have tested (e.g., the Gaoping River basin) (Lee 2014), however, more testing is needed to see if it can be applied in other climatic zones around the world.

The proposed relationship is applied to predict landslide areas for two Typhoon event scenarios. It can be seen that the area would increase by $31.86 \%$ after a single rainstorm event during the period from 2017 - 2090. We also calculated the rainfall volume for the two rainstorm event scenarios, which shows an increase of rain volume by $22.61 \%$. 
Further testing was carried out by applying the new model to find the trend for different homogeneous rainfall events at the Zengwen River basin (Fig. 9). Again, the trend fits a Weibull cumulative distribution function when the rainfall depths are homogeneously distributed throughout the study area. The rainfall threshold is about $200 \mathrm{~mm}$ and the range is about $2000 \mathrm{~mm}$, as shown in Fig. 9. The total landslide areas from both the 2017 event and the 2090 event are very similar to that predicted by the homogeneous rainfall trend, at values of 1355 and $1662 \mathrm{~mm}$, respectively. The rate of increase in landslide area becomes lower and lower after the cumulative rainfall exceeds the range of about $2000 \mathrm{~mm}$.

The present proposed landslide and rainfall relationship may be good for understanding landslide trends and predicting landslide density under an extreme climate event. However, the model is localized and only valid for the study area, the mountainous terrain of the Zengwen River basin, although the proposed methodology and function form may be used in other drainage basin in Taiwan and around the world.
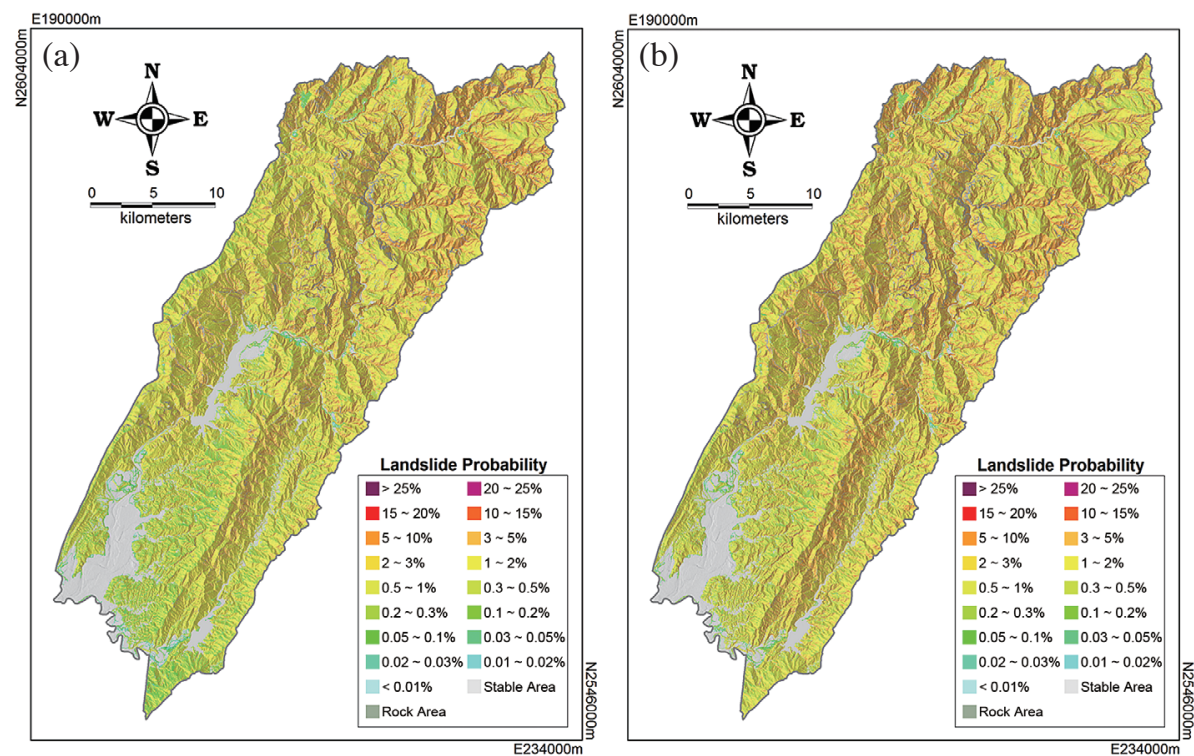

Fig. 8. Landslide predictions based on rainfall estimated from statistical and dynamical downscaling of precipitation: (a) near future rainfall event, 2017, predicting a total landslide area of $19631806 \mathrm{~m}^{2}$ and $2.11 \%$ of the study area; (b) rainfall at the end of the century, 2090, predicting a total landslide area of $25885700 \mathrm{~m}^{2}$ and $2.78 \%$ of the study area. Stable area and rock area are defined in Fig. 6.

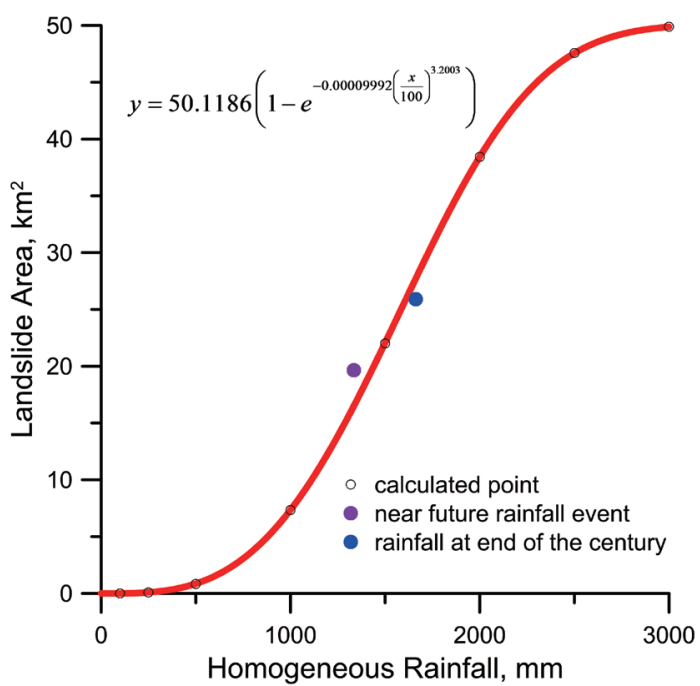

Fig. 9. Landslide trend under different homogenous precipitation amounts for the Zengwen River basin. The open circles indicate the points calculated with Eq. (2), the thick red line indicates the fit of these points to a Weibull cumulative distribution function, the solid purple circle indicates the predicted landslide area for the near future rainfall event, and the solid blue circle indicates the predicted landslide area for a rainfall event at end of the century. 


\section{CONCLUSIONS AND RECOMMENDATIONS}

A new landslide density and rainfall depth relationship is proposed in this study based on landslide and rainfall data sets for the Zengwen River mountainous terrain basin in southwestern Taiwan. This relationship basically follows a Weibull cumulative distribution function if the landslide susceptibility value is fixed. This relationship is applied to find the landslide trend under different homogeneous rainfalls in the study area. It is also applied to predict the landslide occurrence for a near future rainfall event and a rainfall event at the end of this century, estimated from the statistical and dynamic precipitation downscaling. The results indicate that landslide area in the study area will increase by $31.86 \%$ with an increase in rainfall volume of $22.61 \%$ from 2017 2090. Note also that the rate of increase in landslides may become lower when the event cumulative rainfall exceeds about $2000 \mathrm{~mm}$.

This new landslide and rainfall relationship was successfully tested in other drainage basins in Taiwan. However, more testing is still needed in other climatic zones around the world.

Acknowledgements This research was supported by the Ministry of Science and Technology, R.O.C., under Grant Number MOST104-2621-M-019-001.

\section{REFERENCES}

Aleotti, P. and R. Chowdhury, 1999: Landslide hazard assessment: summary review and new perspectives. Bull. Eng. Geol. Environ., 58, 21-44, doi: 10.1007/ s100640050066. [Link]

Bonilla, M. G., 1975: A review of recently active faults in Taiwan. U.S. Geological Survey Open-File Report 7541, version 1.1, $42 \mathrm{pp}$. Available at http://pubs.usgs. gov/of/1975/of75-41/.

Bonilla, M. G., 1977: Summary of quaternary faulting and elevation changes in Taiwan. Mem. Geol. Soc. China, 2, 43-55.

Caine, N., 1980: The rainfall intensity: Duration control of shallow landslides and debris flows. Geogr. Ann. Phys. Geogr., 62, 23-27, doi: 10.2307/520449. [Link]

Carrara, A., 1983: Multivariate models for landslide hazard evaluation. J. Int. Assoc. Math. Geol., 15, 403-426, doi: 10.1007/BF01031290. [Link]

Chung, C. J. F. and A. G. Fabbri, 1999: Probabilistic prediction models for landslide hazard mapping. Photogramm. Eng. Rem. Sens., 65, 1389-1399.

Chung, C. J. F. and A. G. Fabbri, 2003: Validation of spatial prediction models for landslide hazard mapping. Nat. Hazards, 30, 451-472, doi: 10.1023/B:NHAZ.000000 7172.62651.2b. [Link]

Crosta, G., 1998: Regionalization of rainfall thresholds: An aid to landslide hazard evaluation. Environ. Geol., 35, 131-145, doi: 10.1007/s002540050300. [Link]

Dadson, S. J., N. Hovius, H. Chen, W. B. Dade, M. L. Hsieh, S. D. Willett, J. C. Hu, M. J. Horng, M. C. Chen, C. P. Stark, D. Lague, and J. C. Lin, 2003: Links between erosion, runoff variability, and seismicity in the Taiwan orogen. Nature, 426, 648-651, doi: 10.1038/ nature02150. [Link]

Daogi, T., 1971: Rainfall caused hillside collapses. J. Japan Soc. Erosion Contr. Eng., 23, 21-34. (in Japanese)

Finlay, P. J., R. Fell, and P. K. Maguire, 1997: The relationship between the probability of landslide occurrence and rainfall. Can. Geotech. J., 34, 811-824, doi: 10.1139/cgj-34-6-811. [Link]

Goovaerts, P., 1997: Geostatistcs for Natural Resources Evaluation, Oxford University Press, 483 pp.

Guzzetti, F., A. Carrara, M. Cardinali, and P. Reichenbach, 1999: Landslide hazard evaluation: A review of current techniques and their application in a multi-scale Study, Central Italy. Geomorphology, 31, 181-216, doi: 10.1016/s0169-555x(99)00078-1. [Link]

Guzzetti, F., S. Peruccacci, M. Rossi, and C. P. Stark, 2007: Rainfall thresholds for the initiation of landslides in central and southern Europe. Meteorol. Atmos. Phys., 98, 239-267, doi: 10.1007/s00703-007-0262-7. [Link]

Guzzetti, F., S. Peruccacci, M. Rossi, and C. P. Stark, 2008: The rainfall intensity-duration control of shallow landslides and debris flows: an update. Landslides, 5, 3-17, doi: 10.1007/s10346-007-0112-1. [Link]

Ho, C. S., 1975: An Introduction to the Geology of Taiwan - Explanatory Text of the Geologic Map of Taiwan, Central Geological Survey, Ministry of Economic Affairs, Taiwan, $192 \mathrm{pp}$.

Hsu, M. T., 1971: Seismicity of Taiwan and some related problem. Bull. Intern. Inst. Seis. Earthq. Eng., 8, 41-160.

Lee, C. T., 2013: Re-evaluation of factors controlling landslides triggered by the 1999 Chi-Chi Earthquake. In: Ugai, K., H. Yagi, and A. Wakai (Eds.), EarthquakeInduced Landslides, Springer, Berlin, Heidelberg, 213224, doi: 10.1007/978-3-642-32238-9_22. [Link]

Lee, C. T., 2014: Multi-stage statistical landslide hazard analysis: rain-induced landslides. In: Sassa, K., P. Canuti, and Y. Yin (Eds.), Landslide Science for a Safer Geoenvironment, Springer, Cham, 291-298, doi: 10.1007/978-3-319-04996-0_45. [Link]

Lee, C. T., 2015: Review and perspectives on methodology for landslide hazard analysis. Proceedings of 10th Asian Regional Conference of IAEG, 6 pp.

Lee, C. T., C. C. Huang, J. F. Lee, K. L. Pan, M. L. Lin, and J. J. Dong, 2008: Statistical approach to earthquakeinduced landslide susceptibility. Eng. Geol., 100, 43-58, doi: 10.1016/j.enggeo.2008.03.004. [Link]

Liu, J. G., 2000: Smoothing filter-based intensity 
modulation: A spectral preserve image fusion technique for improving spatial details. Int. J. Rem. Sens., 21, 3461-3472, doi: 10.1080/014311600750037499. [Link]

Saito, H., D. Nakayama, and H. Matsuyama, 2010: Relationship between the initiation of a shallow landslide and rainfall intensity-duration thresholds in Japan. Geomorphology, 118, 167-175, doi: 10.1016/j.geomorph.2009.12.016. [Link]

Steer, P., M. Simoes, R. Cattin, and J. B. H. Shyu, 2014: Erosion influences the seismicity of active thrust faults. Nat. Comm., 5, doi: 10.1038/ncomms6564. [Link]

Su, Y. F., J. J. Liou, C. T. Cheng, and A. Kitoh, 2014: Assessment of the change of typhoon rainfall event characteristics using dynamic downscaling data under a climate change scenario. J. Taiwan Agric. Eng., 60,
48-60.

Tan, C. H., Y. H. Chen, and S. Y. Chi, 2009: Evaluation of rainfall threshold of landslide in mountainous drainage basins by a deterministic method. Q. J. Sinotech Eng., 105, 5-16. (in Chinese)

Teng, L. S., 1990: Geotectonic evolution of late Cenozoic arc-continent collision in Taiwan. Tectonophysics, 183, 57-76, doi: 10.1016/0040-1951(90)90188-E. [Link]

Tsai, Y. B., T. L. Teng, J. M. Chiu, and H. L. Liu, 1977: Tectonic implications of the seismicity in the Taiwan region. Mem. Geol. Soc. China, 2, 13-41.

Varnes, D. J. 1984: Landslide Hazard Zonation: A Review of Principles and Practice, UNESCO, Paris, 63 pp.

Yu, S. B., H. Y. Chen, and L. C. Kou, 1997: Velocity field of GPS stations in the Taiwan area. Tectonophysics, 274, 41-59, doi: 10.1016/S0040-1951(96)00297-1. [Link] 